\title{
Malnutrition among school going children in Varanasi
}

\author{
Sushma Tripathi and Archana Chakravarty
}

Malnutrition is major problem in India. Nutrition plays important role in development of growth and development of child. In many developing countries poor nutritional status is mainly due to illiteracy, poverty, least job opportunities etc. Poor hygiene, intestinal infection, worm infestation are another important groups leading malnutrition in India. Malnutrition affects physical growth, morbidity, mortality, cognitive development, reproduction and physical work capacity and it consequently impacts on human performance, health and survival. It is an underlying factor in many diseases for both children and adults. The present study was cross-sectional. The study sample (150) was collected by purposive and random sampling techniques. Maximum children were belonged to age group 10-15 years. Pretested and predesigned questionnaire was used in the survey. Measurements were taken by standard techniques (Jelliffe, 1966). Body mass index (BMI) for boys and girls was calculated by using formula BMI $=$ Weight $(\mathrm{kg}) / \mathrm{Height}^{2}(\mathrm{~m})$ according WHO. It was found that 88 per cent children were underweight, 12 per cent were normal and not a single overweight child was found. The daily food intake of school going children was lower than Recommended Daily Allowances (RDA).

Key Words : Malnutrition, Body mass index, Daily food consumption pattern, Nutritional status, Recommended daily allowance.

How to cite this article : Tripathi, Sushma and Chakravarty, Archana (2015). Malnutrition among school going children in Varanasi. Food Sci. Res. J., 6(1): 14-18.

\footnotetext{
MEMBERS OF RESEARCH FORUM

Author for correspondence :

SUSHMA TRIPATHI, Department of Home Science, Banaras Hindu University, VARANASI (U.P.) INDIA

Email: tri.sushma18@gmail.com

Associate Authors' :

ARCHANA CHAKRAVARTY, Department of Home Science, Banaras Hindu

University, VARANASI (U.P.) INDIA

Email: archana.nutrition@gmail.com
} 